\title{
The Path to Genocide in Northern Uganda
}

\author{
Ogenga Otunnu
}

\begin{abstract}
Uganda, as a territorial state, is the "child" of the late nineteenth century European expansionist violence. Since the construction and consolidation of the despoticallystrong but infrastructurally weak state, the country has witnessed intense political violence, gross violations of human rights, destruction of property, internal displacement and refugee migrations. Today, Acholiland in northern Uganda is ravaged by a genocidal war, internal displacement, refugee migrations, humanitarian disaster and other forms of systematic violations of human rights. Yet, these crises have not received adequate attention from scholars, policy makers, human rights organizations and the rest of the international community. What are the causes of the crises? Why do the crises persist? Who are the protagonists? What are the effects of the crises on the society? Why has the international community failed to respond to the genocide and humanitarian disaster? These are some of the questions this article will attempt to address.
\end{abstract}

\section{Précis}

L'Ouganda, comme entité territoriale, est $l$ ' kenfant we la violence expansionniste européenne de la fin du dix-neuvième siecle. Depuis la constitutiond'un état, fort en terme de prise despotique, mais faible en terme d'organisation infrastructurelle, ce pays a été le théâtre deviolences politiques intenses, de patentes et directes violations des droits humains, de destructions, de déplacements internes et de migrations de réfugiés. Aujourd'hui,l'Acholiland, situé au nord del'Ouganda, est ravagé par une guerre entraînant un génocide, des déplacements internes, la migration de réfugiés,

Ogenga Otunnu, Ph.D., is a Visiting Professor of African History and Third World Politics at Ryerson Polytechnic University, Toronto, and Managing Editor, Refuge, CRS, York University, Toronto. le désastre humanitaireet une multitude deformes de violations systématiques des droits humains. Ces crises multiples $n^{\prime}$ ont pourtant pas encorevraiment attiré l'attention des universitaires, des décideurs, des organisations humanitaires et $d u$ reste de la communauté internationale. Quelles sont les causes de ces crises? Pourquoi se perpétuent-elles? Qui en sont les protagonistes. Quels sont les effets de ces crises sur l'ensemble de la société? Pourquoi la communauté internationale a-t-elle failli au devoir de faire face au génocide et au désastre humanitaire ougandais? Telles sont quelquesunes des questions que cet articleva tenter de soulever.

\section{Working Definitions of Genocide}

Discussions about genocide have produced more confusion than clarity. For one thing there is little agreement on the meaning of the word, the phenomenon it is meant to describe, how to study it, what causes it, how it affects societies, how people respond to it, or what to do with it. Here, the working definitions of genocide provided by R. Lemkin and L. Horowitz are adopted.

$R$. Lemkin defines genocide as follows: an act of deliberate depopulation of a group; the actual physical and biological extermination of an ethnic, racial or religious group; a deliberate measure intended to impoverish and starve a target population; a deliberate measure aimed at undermining the social order of a target population; an act whose objective is to dismantle the community's moral principles; an assault on the culture of a target group that ultimately deprives the group of its identity by means of ethnocide; an act calculated to causemental and physical harm, terrorize, dehumanize and humiliate members of a target group. ${ }^{1}$

L. Horowitz describes a society that is genocidal as follows: a society that tries to resolve problems by destroying a group; a polity that is incarceration-ori- ented, imprisoning as many members of the group as possible; a society that is torture-prone, resorting to inflicting extreme forms of bodily and mental harm on the victims; a society which is harassment-prone, impeding a group's ordinary lifestyle and freedom of movement by a persistent series of annoyances; a polity that is shame-oriented, tending to humiliate or disgrace the target group; and a society that is guilt-prone, inculcating in the group being persecuted a sense of collective self-reproach. ${ }^{2}$

\section{Background: An Overview}

The path to genocide has its origins in the nature of the state, and the profound crisis of legitimacy of the state, its institutions, the incumbents and their challengers. ${ }^{3}$ To begin with, during the phase of colonial penetration, the colonial state was despotically weak and infrastructurally weak. ${ }^{4}$ This state was an important site of violence, genocide and anarchy. While the state, its institutions and the incumbents acquired imperial and international legitimacy, they had a profound crisis of legitimacy among the colonized. ${ }^{5}$ Once the colonial regime consolidated its power, the state became despotically strong and infrastructurally strong. Although state powers provided order and stability, the state, its institutions and the incumbents continued to experience a major crisis of legitimacy. The state also maintained important characteristic features of a genocidal state. ${ }^{6}$

During the period of decolonization, the regime attempted to democratize the polity. This political project weakened the machinery of repression and provided the colonized with the opportunity to openly challenge the legitimacy of the state, its institutions and the incumbents. The result was that violence and lawlessness enveloped the colonial state. Indeed, the violence and anarchy that characterized the period of decolonization were directly related to 
the profound crisis of legitimacy of the state, its institutions and the incumbents. The violence and anarchy also highlighted the re-emergence of a despotically strong but infrastructurally weak state. ${ }^{7}$

The first post-colonial regime inherited a despotically strong but infrastructurally weak state. The state, its institution, the incumbents and their challengers had a profound crisis of legitimacy in some parts of the country. The marriage between the Uganda People's Congress (UPC) and the Kabaka Yekka(KY), and Milton Obote's effort to nominate Sir Edward Mutesa to the Presidency, were some of the attempts made to address the profound crisis of legitimacy of the state and the regime. These attempts made both the state and the regime somewhat despotically weak but infrastructurally strong, except in the war-torn Rwenzori portion of the country. However, the status of the "Lost Counties," the economic crisis that began to ravage the country, and the Cold War politics in the Congo and the rest of the region, eroded the faltering politics of legitimization. In the end, the UPC-KY marriage of legitimization collapsed, leading to a major crisis of legitimacy of the state, its institutions and the incumbents, particularly in Buganda. The result was that violence, repression, gross violations of human rights and lawlessness claimed the political terrain in Buganda. From that moment, both the state and the regime became despotically strong but infrastructurally weak. ${ }^{8}$

In 1971, General Idi Amin seized power. Faced with a profound crisis of legitimacy, the regime massacred many of its challengers, mostly Acholi and Langi. Attempts to address the crisis of legitimacy by the regime included the appointment of somemembers of political parties, some members of major institutionalized religions, and scholars into the cabinet. The return of the Kabaka's remains for national burial, and the expulsion of Asians, were also intended to address the crisis of legitimacy of the regime. However, as regime challengers waged a protracted guerrilla war against the government, the economy continued to decay, and factionalism tore apart the cabinet and the army, both the state and the regime became despotically weak and infrastructurally weak. The result was that anarchy, repression, violence and lawlessness became the order of the day. 9

In 1979, the Uganda National Liberation Front (UNLF) assumed power. Factionalism within the front, violent struggles for power, corruption and dictatorship, the divisive politics of liberation, and protracted guerrilla warfare, preserved the powers of the state and regime: despotically weak and infrastructurally weak. Such a state and regime became an important site of anarchy, violence and repression. In fact, this state, like that of its predecessor, acquired important characteristics of a genocidal state. ${ }^{10}$

When Obote assumed power in 1980 (Obote II), the crisis of legitimacy persisted for a number of reasons: the politics of liberation alienated many people; the results of the elections were violently contested; some of the politicians who were genuinely defeated in the elections, including Yoweri Museveni, took arms to fight to regain power; and those who had been ousted from power waged a protracted guerrilla warfare. The result was that both the state and regime became despotically weak and infrastructurally weak in those parts of the country where armed insurgencies escalated: Buganda and West Nile. In these two regions, anarchy, lawlessness, concentration camps, repression, and genocide violence defined both the state and regime. Regime challengers also became genocidal in these regions: they destroyed property and massacred unarmed civilians. The persecution of Rwandese refugees and Banyarwanda, and the violation of the rights to asylum by some Rwandese refugee warriors also took place during this period.

Profound crisis of legitimacy within the UPC, the cabinet and the army, escalated the anarchy, repression, violence and lawlessness to other sectors of the society. In the end, the faltering regime was toppled in 1985 by a section of the army, led by some Acholi officers.
In July 1985, General Tito Okello seized power. The Okello regime attempted to address the crisis of legitimacy by reaching negotiated settlements with the Democratic Party (DP), the Conservative Party (CP), the Federal Army(FEDEMU), UgandaFreedomArmy (UFA), Uganda Rescue Front (URF), Former Uganda Army (FUNA), and a faction of the UPC. However, attempts to appease the National Resistance Army (NRA), led by Museveni, failed. Its religious commitment to the policy of appeasement and its feverish attempts to anegotiated settlement with the NRA, made the regime neglect its administrative responsibility in the country. The result was that both the regime and the state became so despotically weak and infrastructurally weak that unprecedented anarchy and lawlessness embraced the country. Indeed, it was during this period that state powers became so weak that the state only existed because it was recognized by international laws and international persons. ${ }^{11}$

\section{The Path to Genocide in Northern Uganda}

In January 1986, Museveni seized power. The defeated Gen. Okello and his Uganda National Liberation Army (UNLA) fled to Acholiland and southern Sudan, where the UNLA committed atrocities against unarmed civilians. By the end of March 1986, Lt. Gen. Musevenihad effectively consolidated his power throughout the country, thereby making both the state and the regime despotically strong and infrastructurally strong. During that period, stability returned to every part of the country, including Acholiland. ${ }^{12}$

However, Museveni's army, the NRA, that had been quite disciplined during the period, began to arrest, detain, beat, rape and murder unarmed civilians in Acholiland. Some former members of the UNLA who reported to the NRA and National Resistance Councils (NRC), as requested by the government, were also tortured, and in many instances, murdered by the army. The soldiers also looted livestock and 
other movable property from Acholiland. According to the government, these atrocities, especially those committed in Namokora from May to July 1986, were the work of the 35th Battalion of the NRA. This battalion, it claimed, comprised former members of FEDEMU whohadjoined the NRA after the fall of Kampala. FEDEMU, the regime insisted, comprised mainly of Baganda combatants who decided to avenge the lost their relatives at the hand of the UNLA in the Luwero Triangle during Obote II. The widespread looting by the NRA, it further claimed, was the work of the former members of FEDEMU who wanted to reclaim what had been looted from Buganda by the UNLA during the Luwero war. The atrocities committed against the Acholi, therefore, were presented by the regime as a continuation of ethnic conflict between the Baganda and Acholi. ${ }^{13}$

Former members of FEDEMU, however, claimed that the atrocities were committed by Rwandese and Banyankole members of the NRA. According to this view, the government shifted the responsibility for the atrocities on former members of FEDEMUbecause it had began to discriminate against the Baganda members of the NRA. Also, that the explanation offered by the government was intended, in part, to protect Rwandese refugee warriors in the NRA and NRM against the growing anti-Rwandese sentiments in the country. Furthermore, FEDEMU explained, the 35thibattalion was made up of UFM, not FEDEMU. ${ }^{14}$

The widespread and intense atrocities that the regime of Lt. Gen.Museveni committed, generated a profound crisis of legitimacy in Acholiland. The atrocities and other related acts of terror and systematic violations of human rights by the regime were considered by the Acholi as acts of genocide for a number of reasons. First, the NRA had humiliated the Acholi by defeating them militarily. The humiliation was quite devastating to the Acholibecause some of them believed that they were the most outstanding warriors in Uganda. This belief was partly influenced by the fact that the Acholi had provided a signifi- cant portion of the army in the country for the most part of both the colonial and post-colonial periods. Second, Museveni and his political appointees dehumanized and humiliated the Acholiby repeatedly referring to the ethnic group and its culture as backward and primitive. Genuine grievances by the Acholi were also presented by the regime and its scholars as evidence of inferiority, backwardness and primitiveness. Third, the victimization and murder of some prominent Acholileaders by the regime were seen as attempts to undermine the faltering social order of the group. Fourth, confiscation of livestock, the violent relocation of hundreds of thousands of Acholi to "protected camps" by the government, the pillage of Acholiland, including destruction of crops and water wells by the regime, were seen as measures aimed at impoverishing and starving the target population. Fifth, the widespread rape of both women and men by the NRA, the terror tactics the NRA employed in the area, torture, including kandoya, ${ }^{15}$ and murder of thousands of unarmed civilians, were perceived as deliberate measures calculated to cause mental harm and exterminate the Acholi. ${ }^{16}$

The systematic persecution of the Acholi by the NRA provided one of the anti-regime armed groups, the Uganda People's Democratic Army (UPDA), with popular support in Acholiland. With this support, the UPDA, predominantly Acholi, attacked and captured Ukuti village, near Namokora, in August 1986. The victory of the UPDA was partly aided by the Sudan government which supported the insurgents because the Museveni regime provided arms and political support to the armed opposition group, the Sudan People's Liberation Army (SPLA). ${ }^{17}$

The NRA responded with overwhelming reprisals against unarmed civilians in Namokora. For example, at least 40 civilians were executed in one incident by the NRA. This massacre, among many others by the NRA, forced thousands of people to flee in search of security and protection. ${ }^{18}$ Unfortunately, there was no security and protection in the entire Acholiland. In fact,
Acholiland had become a war zone where armed protagonists targeted unarmed civilians as well. The UPDA, for example, tortured and massacred some unarmed civilians whom it referred to as "traitors." It also waged a protracted and harrowing war against members of another anti-regime armed group, the Holy Spirit Movement (HSM). ${ }^{19}$

The HSM, led by a self-proclaimed prophetess, Alice Auma (Lakwena), became the most dominant anti-regime armed group in Acholiland from late 1986 until its demise at the end of 1987. Like theUPDA, the HSM gained a strong foothold in Acholiland as a direct result of the atrocities committed by the NRA. It also dislodged the UPDA from the area because the latter had become brutal and ineffective. Unlike other insurgency groups in Acholiland, the HSM combined religious idioms and contemporary military strategies to mobilize military and political support from the population in Acholiland, Lango and Teso. Its primary objectives, the HSM claimed, were to remove the genocidal regime of Museveni, cleanse Acholiland and the rest of the country, and institute a regime based on social justice, respect and fear of God.

During its short existence, the HSM fought, won and lost many battles against the NRA. It also tortured, maimed and massacred many unarmed civilians who disagreed with its philosophy or disobeyed its order or failed to adhere to the Ten Commandments, as interpreted by Lakwena and her political aid, Professor Isaac Newton Ojok (Minister of Education in Obote II). Thousands of its supporters also perished in the hands of the NRA because they fought largely using Christian hymns, sticks, stones arrows and bows against a modern army. The NRA further took advantage of the war and tortured, raped, abducted and killed many innocent people in Acholiland, destroyed crops, schools, hospitals and boreholes, and confiscated more livestock from the area. ${ }^{20}$ Another important aspect of the war was that the military engagement between the HSM and the UPDA, and the HSM and the NRA, violently uprooted hundreds of 
thousands of Acholi. The overwhelming majority of the uprooted population languished in the war zone without humanitarian assistance and protection.

The humanitarian crisis and persecution of unarmed civilians in Acholiland continued after the decisive defeat of the HSMby the NRA near Jinja (fifty miles from Kampala) in late 1987. This time, Lakwena's father, Severino Lukoya, reorganized remnants of the defeated HSM, predominantly Acholi, into HSM II. The objectives, tactics and strategies of HSM II remained the same as those of Lakwena's HSM. For example, throughout its brief existence (1988-1989), HSM II terrorized and killed many Acholi whom it perceived as its opponents. It also caused the deaths of hundreds of its supporters who faced the NRA with Christian hymns, sticks, stones, bows and arrows. The NRA responded by adopting the same objectives, tactics and strategies: it burned down more houses and granaries, destroyed more crops and schools, confiscated more livestock, raped, maimed and murdered many more Acholi..21

The path to genocide was further paved by the activities of Joseph Kony's Lord's Resistance Army (LRA). The LRA was formed at about the same time as HSM II in late 1987. Soon, the LRA became the most organized, the strongest and the most brutal insurgency group in Acholi. Like the previous armed opposition groups, it was almost exelusively Acholi. Like the UPDA, it received military assistance from the Sudan government. The Sudan government provided military assistance to the LRA because the SPLA was armed by the Museveni regime. The military assistance the LRA received from the Sudan government; the overwhelming brutality of the NRA in its war of pacification in Acholi; the continuous humiliation and disgrace of the Acholi by the regime; the persistent attempts by the regime to inculcate in the ethnic group being persecuted a sense of collective self-reproach; the unwillingness of the Museveni regime to resolve the crisis in Acholi through a negotiated settlement; the disintegration of the UPDA following the controversial and conflict-laden Pece Peace Agreement; and the demise of the HSMII, strengthened the LRA.

As soon as the LRA gained military prominence in Acholiland, it attacked the NRA, overran a number of military detachments, seized large quantity of arms and ammunition, destroyed a number armoured vehicles, killed many NRA soldiers and captured many more. In fact, the LRA became so powerful that it roamed Acholiland almost without a military challenge from the NRA. It also spread its insurgency activities to Lango and Teso.

The LRA has also attacked, captured, abducted, maimed and killed many members of the Local Defense Units, especially the "bow-and arrow" brigades. The primary roles of the brigades, which comprises exclusively Acholi, are to defend the area against the LRA, and report the presence of LRA and its sympathizers to the NRA. These roles made the brigades an important military target. For example, on April 22, 1995 , the LRA attacked the LDU centre in Atiak in Gulu district. An estimated 72 members of the LDU and unarmed civilians were killed in the attack. Some unarmed civilians, especially women and children were tortured and abducted. ${ }^{22}$

Since 1995, the LRA has actively used land mines in the conflict. The result is that a number of government soldiers, members of the LDU and peasants have been maimed and killed. Also, land mines are often planted near wells and granaries, in farms and along footpaths and roads. This method of warfare has made Acholiland extremely dangerous, especially for women who travel long distances to fetch water and collect firewood, and peasants who must till the land for subsistence.

Another form of warfare the LRA continues to use in the conflict is abduction of women and children. For example, in March 1989, it abducted 10 girls from St. Mary's College Aboke, in Lango. In October 1996, it abducted 152 girls from the same school. After the headmistress of the school appealed to the commanders of the LRA, 109 girls were released. While some of the women and children who were abducted become soldiers, others were forced to become wives of LRA officers. Girls and boys who escaped from the LRA report of systematic rape, mutilation and other forms of torture experienced by the victims who were unable to walk the long and difficult journey with the LRA. ${ }^{23}$

TheNRA/Uganda People's Defence Force(UPDF) responded to the presence of the LRA by planting land mines in various places in Acholiland. Most of the land mines were manufactured by the army in Nakasongola near Bombo. The army has also attempted to contain the insurgency by executing suspected LRA collaborators. In some instances, the army hands over those it has branded LRA collaborators to mobs to beat them to death. For example, on August 16, 1996, the UPDF handed over a number of suspected LRA collaborators to a mob in Gulu town. As ordered by the army, the mob beat the suspects to death. This incident took place in the presence of the 4th Division Commander, Col. J. Kazini, and the Deputy Commander of the Division, Major. S. Ssemakula. Col. Kazini has since been promoted to the rank of a Brigadier and has become the Army Chief of Staff. ${ }^{24}$

In its protracted war of pacification, the UPDF has destroyed many homes and killed many unarmed civilians in Acholiland. The systematic destruction of homes and massacres of unarmed civilians have resulted, in part, from the repeated and unrestrained use of helicopter gunships to dislodge the LRA. For example, on August 31, 1995, an estimated 100 homes were destroyed and 210 unarmed civilians were killed in Lukung, near Kitgum, when one of the helicopter gunships opened fire on what the NRA described as a column of LRA. Many more civilians have been executed by the army, even in areas that are under its control. For example, in what is popularly known as the "Kitgum District Bar Incident of 1995," the army killed 38 and injured 8 civilians who were drinking in a bar in Kitgum. ${ }^{25}$

The systematic use of terror, abduction, mass rape, harsh beatings during 
questioning, mass detention of civilians and other forms of torture against civilians have increased in the counter-insurgency in Acholiland. For example, $\mathbf{R}$. Gersony in The Anguish of Northern Uganda, notes that:

Brutal beating of civilians during questioning in rural areas was described as routine. This is reported not only when army patrols reach villages through which rebels may have passed, or which they believe to be collaborating with the LRA ... Rape appears to be a continuing problem. ${ }^{26}$

Gersony further notes that:

A widespread complaint in Gulu town is that at night the UPDF soldiers in civilian dress, or civilian thugs with whom suchsoldiers collaborate, prey upon the civilian population through looting and-in isolated cases-killing of those who resist ... A number of cases have apparently been confirmed by the local authorities. ${ }^{27}$

D. Mowson, a representative of Amnesty International at the "Kacoke Madit" in London in July 1998, also noted that, "while rebels are guilty of widespread human rights abuses, UPDF has, over the years, also been caught red-handed committing similar atrocities." 28

Another strategy that the UPDF has adopted in the war against the LRA is to forcibly relocate a large number of the civilian population to "protected camps." For example, in October 1996, the UPDF forced over 100,000 people in Gulu to relocate to a "protected camp." As a recent report observes,

In most cases, civilians were given a three-day deadline for moving. Although reluctant to leave their homes, they were advised that if found in rural areas they would be treated as "rebels." The Government had made no advance arrangements for health, sanitation, food or other assistance, aggravating the increased infant mortality which predictably arose in these locations. ${ }^{29}$

The violent relocation of unarmed civilians into camps is intended to achieve a number of objectives: make it difficult for the rebels to mobilize new recruits; deprive the rebels of food supplies and other support from the population; punish the Acholi for not voting for Museveni in the 1996 election; and deter the insurgents from attacking army detachments in Acholiland. It is hoped that the violent relocation would deter the LRA from attacking the detachments because the insurgents would have to kill theirown people in the camp before they can destroy army detachments which are located in the camps. The government, however, suggests that its military strategy is intended to reduce the number of civilian fatalities during counter-insurgency in the area.

\section{Humanitarian Disaster and the Myths of Protection in "Protected Camps."}

There are two categories of the civilian population that are internally displaced. The first comprises hundreds of thousands of civilians who were forced by the government to abandon their homes and farms for "protected camps." Those who were violently uprooted by the UPDF from their homes in Gulu in October 1996 belong to this category. The UN Assessment Mission (1997) also notes that 14 other "protected camps" that were created in 1996 and 1.997 by the UPDF in Gulu District belong to this group. As J. Rone observes, camps that belong to this category were created through violence by UPDF:

[T]hose [civilians] who chose to remain behind were ordered to move to the camps by the UPDF officers ... in some cases were beaten if refused to move. A number of witnesses claimed that the UPDF shelled near reluctant villages in order to create fear and force the civilians to move. ${ }^{30}$

The second comprises those civilians who fled to the "protected camps" because of unrestrained terror by both the LRA and UPDF. Members of both categories, who number over 470,900 , were violently and involuntarily uprooted from theirhomes to the camps (see tables 1 and 2). Almost half of those in the camps are children under 5 years old and women (see table 3 ).
Table 1: Conservative Estimates of the Number of Internally Displaced Persons (IDPS) per Camp in Gulu District

\begin{tabular}{lrr}
\hline Sub-division & County & $\begin{array}{r}\text { Number } \\
\text { of IDPs }\end{array}$ \\
\hline Amuru & Kilak & 32,000 \\
Awe & Kilak & 11,000 \\
Pabo & Kilak & 20,000 \\
Atiak & Kilak & 14,000 \\
Awach & Aswa & 8,000 \\
Onyama & Aswa & 6,000 \\
Coo-pe & Aswa & 9,000 \\
Palaro & Aswa & 4,000 \\
Labwonyaro-moo & Aswa & 5,000 \\
Patiko & Aswa & 7,000 \\
Gwenya-deyo & Aswa & 6,500 \\
Cwero & Aswa & 5,200 \\
Alero & Nwoya & 28,000 \\
Anaka & Nwoya & 36,000 \\
Koc-Goma & Nwoya & 5,000 \\
Koc-Ongako & Nwoya & 7,000 \\
Acet & Omoro & 16,000 \\
Odek & Omoro & 11,000 \\
Bobi & Omoro & 7,000 \\
Lakwara & Omoro & 6,000 \\
Gulu & Municipality & 50,000 \\
Total & & $297,400 *$ \\
\hline & &
\end{tabular}

Table 2: Conservative Estimates of the Number of Internally

Displaced Persons (IDPS) per Camp in Kitgum District

\begin{tabular}{lcr}
\hline Sub-division & County & $\begin{array}{r}\text { Number } \\
\text { of IDPs }\end{array}$ \\
\hline Lacek-Ocot & Aruu & 7,500 \\
Acholi-Buu & Aruu & 5,000 \\
Pajule & Aruu & 22,000 \\
Kalongo & Agago & 6,000 \\
Patongo & Agago & 21,000 \\
Palabek-Kal & Lamwo & 9,000 \\
Padibe & Lamwo & 7,000 \\
Nam-Okora & Chua & 20,000 \\
Kitgum & Town & 50,000 \\
Total & & 147,500 \\
\hline
\end{tabular}

- There are 26,000 Acholi who fled and live in camps in Kigumba and Karuma in Masindi District.

Source: n.a., Internal Displacement in Acholi, 1998. n.p. Deposited at the Wider Consultation on Uganda (WiCU), London. 
Table 3: Children under FiveYears Old and Women Living in Displaced Camps in Gulu District

\begin{tabular}{lr}
\hline Camp & Population \\
\hline Acet & 3,500 \\
Alero & 6,600 \\
Amuru & 23,306 \\
Anaka & 2,500 \\
Awach & 13,613 \\
Awer & 3,733 \\
Koch Goma & 10,000 \\
Lalogi & 1,853 \\
Olwal & 6,893 \\
Opit & 7,483 \\
Pabo & 42,556 \\
Pagak & 8,303 \\
Palaro & 7,600 \\
Patiko/Ajulu & 9,511 \\
Unyama & 3,134 \\
Angung & 758 \\
Apyeta & 1,800 \\
Co-pe & 1,500 \\
Cwero & 5,212 \\
Kaladima & 1,344 \\
Labongo Gali & 4,397 \\
Paicho & 6,847 \\
Palenga & 4,000 \\
Parabongo & 6,000 \\
Total & 208,443 \\
\hline
\end{tabular}

Source: Anne-marie dos Reis Mendes, Nutritional Survey: Children under 5 Years Old and Female Adults living in Displaced Camps in Gulu District, Uganda, Action Contre la Faim-USA, April 1998.

The internally displaced persons live in overcrowded camps without sanitation, clean and adequate water, basic medical services and adequate food. In June and July 1998, it was widely reported in Uganda that the little food that the IDPs receive in the camps contains broken glass. The result of the inhumane conditions is that children are not only malnourished, but are dying in large number from measles, malaria, cholera and dysentery. For example, Gulu District Medical Officer, Dr. Paul Onek, notes that 12 children died in UPDF protected campsin Kaunda ground and Pece Community Centre in Gulu between October 16 and 22, 1996. This figure is representative of the high infant mortality in the camps. Onekconcludes his reportby observing that more people are dying daily from secondary effects of the war than from the war. ${ }^{31}$ Pece camp leader, Mary Layado, also notes that many people are dying of starvation and diseases related to overcrowding and lack of food. She attributes the deaths and starvation to "lack of food and drugs from both the government and NGOs." 32 According to a Government Settlement Officer in Charge of Refugee Integration, lack of food is partly caused by the UPDF and government officials:

In certain cases, humanitarian assistance meant for the IDPs has always [sic] been diverted by Government forces. Government troops in some instances have used food assistance meant for the internally displaced. In addition, government officials entrusted with the task of managing relief are known to have diverted it for their own use. ${ }^{33}$

The humanitarian crisis is exacerbated by the destruction of granaries and crops by the army and rebels, confiscation of livestockby the army, land mines, the harrowing war and terror which have persisted for over 12 years, and recurring droughts and famines in the area.

The humanitarian crisis has resulted in part from the reluctance of many international humanitarian organizations to provide assistance to the IDPs in the camps. The response of the humanitarian organizations is based on the following reasons: the violent relocation of the population to the camps by theUPDF which suggests that the camps were constructed to protect theinterests of the government, not those of the civilians; the unwillingness of the government to arrange for basic material well-being of the population as required by the Geneva Convention; the co-location of the "protected camps" or "protected barracks" and military detachments in places such as Pabo and Amuru that make the civilians a first line of attack by the rebels against the army; confiscation of humanitarian assistance by the UPDF; the unwillingness of the UPDF to provide protection to the "protected camps;" the failure or unwillingness of the government to end the war that has ravaged the area for over a decade; the reluctance by the government toprovide full and free access to humanitarian and human rights organizations and the media; the determination of the government to withhold or distort information about the nature, intensity and magnitude of the humanitarian crisis in Acholiland; and the unwillingness of the government to declare Acholiland a "disaster zone." The unwillingness of the government to declare Acholiland a disaster zone, the organizations claim, is a result of government's propaganda which suggests that there is no humanitarian crisis in Acholiland, and that the government is in full control of the situation in the area. Given the fact that the "protected camps" were not created to protect the population, the organizations further maintain, providing assistance to them violate the neutrality required to protect the IDPs. Some humanitarian organizations have alșo refused to provide humanitarian assistance because of the pervasive insecurity in Acholiland. ${ }^{34}$

The government, however, denies the accusations made by some humanitarian organizations. It claims that, although there are serious problems in the camps, they do not amount to a humanitarian disaster. The situation in Acholiland, it further insists, is under control. In fact, it suggests that the insurgencies donot pose any serious security problems to the civilian population in Acholiland. Furthermore, it maintains that everything possible is being done to protect the IDPs from the violence of the LRA. What humanitarian organizations should do, it urges, is to respect the sovereignty of the state and provide assistance in a manner similar to what is being done by humanitarian agencies in other parts of the country. ${ }^{35}$

While the debates about humanitarian assistance persist, the IDPs in Acholiland continue to perish. They also faced increased insecurity and severe lack of protection in the "protected camps." Indeed, both the UPDF and the LRA abduct, rape, terrorize and murder IDPs. For example, in late June 1998, the 
Presidential Advisor, Major Kakoza Mutale, arrested and tortured over 150 IDPs from "protected camps" in Gulu. In an attempt to justify the persecution of the IDPs, hebranded them supporters of rebels. The action of the Presidential Advisor forced the members of parliament from Acholi to accuse him "of arresting innocent civilians from Gulu protected camps and branding them rebel collaborators." The MP vowed to kill him, if he dared cross back into Acholiland. ${ }^{36}$ In June 1998, the LRA attacked the camp at Lacekocot in Kitgum District and abducted 20IDPs. The attack, one in a serious of similar incidents, forced an estimated 28,000 IDPs to threaten to desert the camp because the army had not only failed to protect them, but had become a major source of insecurity and terror..$^{37}$ Thus, a government Settlement Officer in Charge of Refugee Integration observes that:

Whereas IDPs in northern Uganda ... fled their homes due to insecurity, attacks on their camps have continued in areas where they fled to. Newspaper reports have quoted both rebels and government forces continuing harassing displaced persons.

Prisons in Gulu and Kitgum, he further notes, "are full of IDPs as tax defaulters." He concludes his observation by pointing out that, besides suffering from intimidation, rape, harassment and abductions, the IDPs have lost property to both LRA and UPDF. ${ }^{38}$

\section{The Myth of Asylum by the Victims of the Path to Genocide}

Although systematic and gross violations of human rights by both the Museveni regime and its armed challengers have persisted for nearly 12 years, those who escaped persecution from Acholiland are often denied asylum by democratic and industrialized governments, especially Canada, Sweden, Norway, the United Kingdom and the United States. Contrary to overwhelming evidence, governments of these states maintain that the Museveni regime is democratic, protects and enhances human rights, and provides peace, stability and protection to the people in Acholiland. The support for the Musevenigovernment, which translates into denying asylum to people from Acholiland, is based on the following: Uganda's unwavering commitment to the Structural Adjustment Programs (SAPs) of the World Bankand International Monetary Fund (IMF); Uganda's commitment to protect and enhance the economic and political interests of some Western states in the Great Lakes region; the insignificance of human rights and democratic practice as legitimate criteria for supporting governments in Africa; the humanitarian fatigue and foreign policy crises in the West that suggest theneed to defend the status quo; the ability of the Museveni regime to control the most visible, populous and sensitive portions of the country; reports and publications by scholars and humanitarian and human rights organizations that distort the nature, intensity and magnitude of the crisis in Acholiland; the effective and efficient propaganda of the government throughits lobbies and scholars in many capitals, including Washington, London and Ottawa; and the refugee deterrence policies of Western governments.

An account of an Acholi refugee woman in the United Kingdom will demonstrate the myth of asylum by genuine refugees from Acholiland. The refugee woman, whose family was one of the wealthiest in Acholiland, fled to the UK in May 1997. Her story was verified by many people, including the author, Cathy Majtenyi (journalist for the Catholic Register, Toronto) who carried out a field research in Kitgum and Gulu, four Acholi elders who attended "Kacoke Madit" in 1998, and a prominent church leader in Kitgum. Here is the voice of the refugee woman:

My daughter who was studying in a secondary school in Kitgum was abducted by the LRA in late October 1996. She was raped many times by the rebels. Luckily, she managed to escape. After trekking for many days, she reached Kitgum. Since my husband had appealed to the UPDF to locate her, he took her to the army to report her return. Surprisingly, the army described my daughter as a spy for the LRA. She was then terrorized and asked to identify LRA collaborators in Kitgum. The army terrorized her partly because one of our relatives is a member of the LRA. Thereafter, some army officers threatened that I surrender my houses and factory in Kitgum to them, if I wanted my family to stay alive. The same officers claimed that I was also spying for the LRA because one of my relatives is a member of the LRA. In early January 1997, the army attacked my house, killing two of my servants at night and setting the two buildings on fire. In late March 1997, I was ambushed by the UPDF. In the ambush, my lorry was destroyed and I was shot. Although the bullet was later removed from my body, I am still receiving treatment in London.

While the UPDF was terrorizing us, the LRA was also busy threatening our lives. According to some LRA supporters in Kitgum, the LRA was going to eliminate us because my daughter revealed the identity of LRA officers and the location of LRA units in Kitgum. We also received numerous death threats from ordinary people who were in the protected camps. These people wanted to kill us because some of their relatives had been abducted or killed by the LRA. Another reason why they wanted to kill us was because of our relative who is a member of the LRA. The persecution we faced from the government, rebels and ordinary people, discouraged us from seeking protection in the camps. In fact, the camps are not safe because people are abducted, raped and killed by the LRA, supporters of LRA, UPDF, government supporters, and aggrieved civilians.

When I arrived in the United Kingdom in May 1997, I was too scared to apply for asylum because I was told that many Acholi were being deported to Uganda. I was also too uncomfortable to share my trauma and that of my daughter with anybody. About a month after my arrival, my daughter joined me in London. Upon her arrival, she applied for asylum. A few months later, I applied for asylum. To our surprise, the British government rejected our applications. Yet, two of my sons have been 
granted indefinite leave to stay in the country. Furthermore, everybody in Kitgum knows what happened to me, my daughter and the rest of my family. Even a prominent church leader from Kitgum has confirmed most of our stories. Of course, he could not write much about my daughter because we learnt that she was actually abducted by the UPDF, not LRA. My son, you interviewed us in Kitgum in April 1997 while you were collecting information about the war. You approached us because you had heard from other people in Kitgum what had happened to us.

Both my daughter and I have nightmares. We are sleepless because the decision by the British government has forced us to re-live the persecution we suffered in Uganda. My son, tell me: who is a refugee? Is it not someone like me or my daughter who has been persecuted by everyone: the government, rebels, supporters of the government, supporters of the LRA, and ordinary civilians who took the law into their own hands? Who should protect people like us? Ihear the British talk about human rights, but do I have human rights? Does my daughter have human rights? Do the people who are dying at home have rights?

\section{Conclusion}

In May 1997, a government official in Gulu told a conference that an estimated 50 percent of the entire Acholi population-over 300,000 Acholi-have perished in the protracted war since 1986. Based on other reports as well, the DP adopted the estimate and demanded an investigation into possible genocide in Acholiland. The DP based its demand, in part, on the United Nations Security Council resolutions on genocide. It also called for a judicial investigation into massacres, mass rapes and torture carried out against unarmed civilians in Acholiland by the UPDF. ${ }^{39}$

In a similar view, the Rt. Rev. Bishop Onono-Onweng of the Diocese of Northern Uganda paints a picture of genocide in Acholiland: massacre of civilians, mass rape, widespread terror and lack of protection in Acholiland, starvation and deaths from diseases related to star- vation, lack of basic health care, and destruction of schools and hospitals by both the LRA and UPDF. ${ }^{40}$ The Resident District Commissioner of Kitgum, George Odwong, added that:

The consequences of this insurgency are numerous and obvious. Over time, the people and their social codes have become overwhelmed and disorganized by the magnitude of this problem. Testimonies of awful experiences among all categories of people reveal the extent to which people have suffered physically and psychologically. As a result of the degradation of the status of the people, they are now compelled to live under very stressful conditions like displacement, abduction, deprivation, victimization, humiliation, separation, and institutionalization. ${ }^{41}$

An elder from Gulu who attended the "Kacoke Madit" in London in July 1998 made a similar observation:

It seems that both the government and the rebels are determined to exterminate the Acholi. The overwhelming majority of government troops and members of the LDU who are killed by the LRA are Acholi. Members of the LRA who are killed by the UPDF are Acholi. Innocent people who are abducted, raped, terrorized and killed by the UPDF and the LRA are Acholi. So, whenever the government celebrates the massacre of the rebels, it is celebrating the death of Acholi. Similarly, whenever the rebels celebrate the massacre of government troops, it is celebrating the death of Acholi ... Almost 90 percent of the entire population of Acholiland is in concentration camps, without food, security, human rights and human dignity. Additionally, it is estimated that over 300,000 Acholi have died as a result of the war. Isn't this genocide? ${ }^{42}$

The foregoing observations are consistent with the working definitions of genocide adopted in this study.

Efforts to end the genocide are being led by religious leaders, Acholi Parliamentary Group (APG), Wider Consultation on Uganda (WiCU), Kacoke Madit and other informal groups. These groups are exerting pressure on both the government and LRA to reach a negotiated settlement. For example, during a meeting organized by religious leaders, with the support of the UNDP (June 28, 1998), appeals were made to both the government and the LRA to negotiate a settlement. The meeting also called for reconciliation that focuses, in part, on the need to adopt traditional Acholi conflict resolution mechanisms. Also, Bedo Piny Pi Kuc (Sitting Down for Peace), as the meeting was referred to, highlighted reasons why the genocidal war has dragged on for 12 years: lack of morale among theNRA/UPDF; the unwillingness of the protagonists to find a peaceful solution to the conflict; the support being provided to the SPLA/ SPLM by the Museveni regime; the support being provided to the LRA by the government of Sudan; opposition to a negotiated settlement by some highranking UPDF officers and powerful civilians who are benefiting from the war; the active involvement of some powerful Western governments in the war by using Uganda and Acholiland as a base to fight against the Sudan government; and the profound crisis of legitimacy of the Museveni regime in Acholiland. ${ }^{43}$

In a similar vein, Kacoke Madit (KM)-which brought together nonpartisans, supporters of the regime and opponents of the regime-called for a negotiated settlement and reconciliation to end the war in Acholiland. In its London resolutions of July 19,1998, KM deplored "the heartless and manipulative role being played by certain foreign powers, non-governmental organizations, and individuals who have vested interest in the perpetuation of the conflict." It also underscored the urgent need for humanitarian assistance to be taken to the people of northern Uganda who are dying of starvation. Another important resolution called upon the government of Uganda to declare Acholiland a disaster zone so that the international community may respond urgently to the humanitarian crisis. Kacoke Madit also called upon the Museveni regime to adhere toits constitutional obligation to protect the lives and property of its citizens in Acholiland. ${ }^{44}$ 
Track Twoor people-to-peoplediplomacy that these groups have embarked on, offers important channels of communication and creates options for negotiated settlements. However, this approach should be complemented by Track One diplomacy, where official representatives of governments, regional and international organizations play active roles. Track One diplomacy brings more resources, incentives, muscle and higher prestige to mediation than Track Two diplomacy. Official mediators may also improve the chances of a negotiated settlement. This is particularly important because the Museveni depends on military and diplomatic assistance from Canada, United Kingdom, the United States, Sweden, Norway and other industrialized states. The LRA, for its part, depends on military support from the Sudan.

Mediation should be supported by sanction regimes and forceful actions to ensure compliance from the LRA and the Museveni regime. Both parties to the conflict should be denied the ability to resupply arms, ammunition, and hard currency. Preventative action should focus on creating political, economic and military barriers to lower the level of armed engagement. There is also urgent need to carry out a massive humanitarian operations to halt the genocide. Equally, there is an urgent need to have mediators that are perceived by both parties to the conflict as fair and just. This perception is important if a highquality and durable settlement is to be reached.Scholars, international organizations, the media, human rights and humanitarian organizations should expose violations of human rights and support a negotiated settlement to the war. The general public also has an important role to play: itshould petition respective political leaders and governments to support a negotiated settlement and policies that protect human rights. ${ }^{45}$

Halting genocide in Acholiland and the raging wars in other parts of Uganda requires a coordinated national, regional, continental and international approach to early warning and early response, conflict resolution and hu- manitarian intervention. It is only by adopting such a policy that the genocidal wars in the Sudan and Burundi will also be brought to an end. The ravaging war in the Democratic Republic of Congo also requires a similar approach. This war resulted, in part, from attempts by Uganda and Rwanda, heavily armed by South Africa and the United States, to use Congolese-Tutsi to topple the despotic regime of President Kabila. With the military support that Kabila has obtained from Zimbabwe, Angola and Namibia, the war has sucked in many African countries. The escalation of this warhas not only shuttered the myths of a new generation of African leaders, but has also called into question the legitimacy of the state, the incumbents, their challengers and supporters. Equally, the war threatens to tear apart the faltering continent. This war will also generate more refugees and internally displaced persons, and consume the scarce resources needed to contain the socioeconomic decay and political upheavals in Africa.

\section{Notes}

1. R. Lemkin, Axis Rule in Occupied Europe (Washington, DC: Carnegie Endowment for International Peace, 1974).

2. L. Horowitz, Taking Lives: Genocide and State Power (New Brunswick, NJ: Transaction, 1982). See also, F. Chalk and K. Jonassohn, The History and Sociology of Genocide: Analyses and Case Studies (New Haven, CT: Yale University Press, 1990), especially 29; L. Kuper, Genocide: Its Political Use in the Twentieth Century (New Haven, CT: Yale University Press, 1981).

3. For working definitions of legitimacy see, for a start, J. H. Scholar, The Legitimacy in Modern State (New Brunswick, NJ and London, U.K.: Transaction Books, 1981), 17-30; A. Moulakis, ed., Legitimacy (Berlin and New York: Walter de Gruyer, 1986), 25; R. Barker, Political Legitimacy and the State (Oxford: Clarendon Press, 1990), 559. N.N. Kittrie, The War Against Authority: From Crisis of Legitimacy to Social Contract (Baltimore/London: The Johns Hopkins Press, 1995), highlights tensions, instability and violence that emanate from a crisis of legitimacy.

4. For informed debates about state powers, see J. A. Hall, ed., States in History (Oxford: Basil Blackwell, 1986).

5. Thelegitimacy of both thestate and regime werebased on imperial European interna- tional laws (the Berlin Conference of 18841885) and agreements which Britain reached with other imperial powers interested in the territory.

6. SeeO. Otunnu, Political Violence in Uganda, 1890-1998 (Forthcoming, 1999), chap. 2.

7. Ibid.

8. Ibid., chap. 3 .

9. Ibid., chap. 4.

10. Ibid., chapter 5.

11. Ibid., chapter 7.

12. See, for example, R. Gersony, The Anguish of Northern Uganda Results of a Field-Based Assessment of the Civil Conflicts in Northern Uganda, a Study Commissioned by the United States Embassy, Kampala and USAID Mission, Kampala, August 1997, 13.

13. See O. Otunnu, "Uganda and the Rise of RPF," in H. Adelman and A. Suhrke, eds., The Path of Genocide: The Rwanda Crisis from Uganda to Zaire (New Brunswick, NJ. Transaction Books, Fall, 1998), chap. 2; Political Violence in Uganda, 1890-1998, chap. 8 (Forthcoming, 1999). See also, Amnesty International, Uganda: The failure to Safeguard Human Rights (London: AI, 1992), 11.

14. O. Otunnu, "Rwandese Refugees and Immigrants in Uganda," in Adelman and Suhrke, eds., The Path to Genocide, chap.1, and "Uganda and the RPF," in The Path to Genocide, chap. 2, explain why and how Rwandese refugees in Uganda joined the NRA/NRM, and the growing antiRwandesesentiments in Uganda. Seealso, Six Baganda, former members of FEDEMU, interviews by the author, London, July 13 and 15, 1998.

15. According to Amnesty International, Uganda: The Failure to Safeguard Human Rights (London: AI, 1992), 87, "Kadoya, alsoknown as 'three-piece tying,' involves tying the victim's arms together above the elbows, behind the back. It is extremely painful, putting great pressure on the chest, causing difficulties in breathing and sometimes permanent damage to the arms. A variation, known as 'briefcase,' involves the victim's legs also being tied behind his back. The victim may then be suspended above the ground."

16. Sixty-eight Acholi elders, interviews by authors, December 1987 and July 1988, Kitgum, Gulu and London. Later human rights organizations and the press reported these gross violations of human rights by theNRA. According to A. Rake,"Museveni must act," New Africa, November 1989, 27, observes that "once disciplined National Resistance Army has been shown to have become as brutal and haphazard as those of Idi Amin and Milton Obote at their 
worst. This is not just our view. It has been borne out by Amnesty International and by the Uganda press (even the government press)." See also, Uganda Law Society, Matters of Concern to Uganda Law Society (Kampala: Uganda Law Society, April 9, 1990), 1-11; "Law Society Hits at Government Record," Weekly Topic, Kampala, Friday, 27 April 1990, 16; Amnesty International, Uganda-Death in the Countryside: Killings of Civilians by the Army (London: AI, December 1990), Extrajudicial Executions (London: AI, April 29, 1991), Uganda: The Failure to Safeguard Human Rights, (London: AI, 1992), 10-62, 70-81; Report of the Committee on International Human Rights of the Association of the Bar of the City of New York, Uganda at Crossroads-A Report on Current Human Rights Conditions, July 1991, especially 29-32.

17. See, for a start, Gersony, The Anguish of Northern Uganda, 22.

18. Amnesty International, Uganda: The Failure to Safeguard Human Rights, 19-62, highlights numerous extrajudicial executions, massacres and other forms of gross violations of human rights by the NRA in Acholiland, Lango, Teso and Buganda.

19. Otunnu, Political Violence in Uganda, chap. 8.

20. See, for example, Amnesty International, Uganda: The Failure to Safeguard Human Rights, 13-66; Gersony, The Anguish of Northern Uganda, 24-25.

21. Otunnu, Political Violence in Uganda, 18901998, chapter eight. See also Amnesty International, Uganda: Failure to Safeguard Human Rights, 10-81; Gersony, The Anguish of Northern Uganda, 29.

22. See, for example, Gersony, The Anguish of Northern Uganda, 38.

23. For elaborate accounts of abductions and torture of women and children by the LRA, see Human Rights Watch, The Scars of
Death: Children Abducted by the Lord's Resistance Army in Uganda (Washington, DC: HRW, 1997); Amnesty International, Breaking God's Command: The Destruction of Childhood by the Lord's Resistance Army (London: AI, 1997); Human Rights Watch, Crises in Sudan and Northern Uganda: Testimony of Jemera Rone, Human Rights Watch, Before the House Subcommittee on International Operations and Human Rights and Subcommittee on Africa, July 29, 1998 (New York: HRW, 1998), especially 14-17.

24. See Gersony, The Anguish of Northern Uganda, 45.

25. Otunnu, Political Violence in Uganda, 18901998, chap. 8. Gersony, The Anguish of Northern Uganda, 45-46, provides a lower estimates of the homes destroyed and the civilians killed by the UPDF in the two incidents.

26. Gersony, The Anguish of Northern Uganda, 46-47.

27. Gersony, The Anguish of Northern Uganda, 47.

28. See The Monitor, Kampala, Monday, July 20, 1998, 2. See also, State Department, Uganda: Country Report on Human Rights Practices, 1997 (Washington, DC: State Department, 1998).

29. Gersony, The Anguish of Northern Uganda, 48.

30. Human Rights Watch, Crises in Sudan and Northern Uganda, 13.

31. See "12 Die in UPDF Protected Villages," Monitor, June, 1997. See also "UN Seeks Food for North," The New Vision, Monday, 26 April 1997, 40.

32. See "12Kids Diein Gulu Camps," The New Vision, Wednesday, 25 June 1997, 11.

33. Mugumya, Uganda's Internally Displaced Persons, 20.

34. Five officials of three major humanitarian organizations based in Kampala. Conver- sation with author, London, July 1998. See also, Gersony, The Anguish of Northern Uganda, 50-51; Mugumya, Uganda's Internally Displaced Persons, 15-16.

35. See, for example, G. Mugumya, Uganda's Internally Displaced Persons: Towards Durable Solution (Kampala, Ministry of Local Government, 1997), 15-16; "12 Die in UPDF Protected Camps," Monitor, Wednesday, October 30-01 November, 1996.

36. See The Monitor, 1 July 1998, 7.

37. See, for example, New Vision, Monday, 29 June 1998, 10.

38. Mugumya, Uganda's Internally Displaced Persons: Towards Durable Solution, 18, 22, and 26.

39. See the Democratic Party, Northern Uganda-Towards a Durable Solution: Peace, Justice and Democratic Self-Governance with Reconciliation and Development, Kampala, May 19, 1997.

40. The Rt. Rev. Bishop Nelson OnonoOnweng, quoted in "Acholi Leaders Seek Peace for War-torn Northern Uganda," EIR (London), 7 August 1998, 59-61.

41. George Odwong, Resident District Commissioner of Kitgum, quoted in "Acholi Leaders Seek Peace for War-torn Northern Uganda," 58.

42. Anelder from Gulu, 72 yearsold, interview with the author, London, July 20, 1998.

43. Declaration of the Bedo Piny on Peace and Reconciliation in Acholiland, Gulu, June 2628,1998 . Efforts to use Track Two Diplomacy in the conflict is described at length by D. Pain, "The Bending of Spear," December 1997. Unpublished report deposited at WiCU.

44. Kacoke Madit, Resolutions, 1998.

45. See Otunnu, "Conflict and Conflict Resolution," Refuge 16, no. 6 (December 1997): 3-5. a

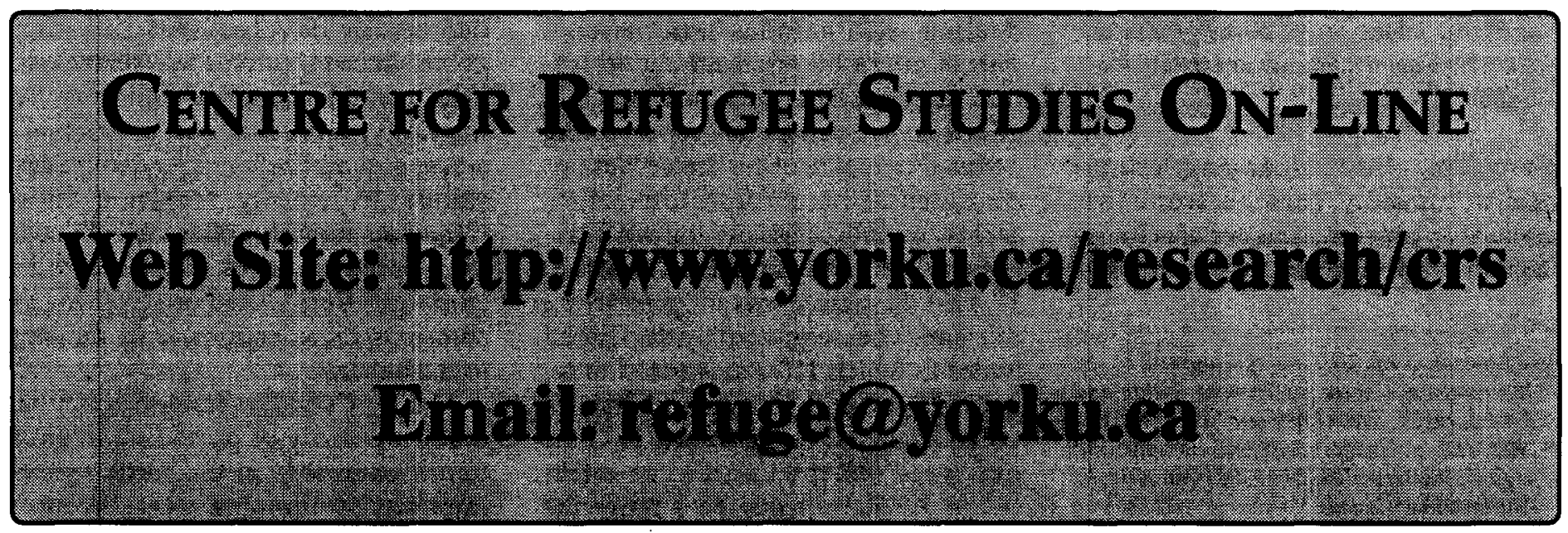

